\title{
Defective ZnCo2O4 with Zn vacancies: Synthesis, property and electrochemical
} application

Huang, Guoyong; Yang, Yue; Sun, Hongyu; Xu, Shengming; Wang, Junlian; Ahmad, Mashkoor; Xu, Zhenghe

Published in:

Journal of Alloys and Compounds

Link to article, DOI:

10.1016/j.jallcom.2017.07.136

Publication date:

2017

Document Version

Peer reviewed version

Link back to DTU Orbit

Citation (APA):

Huang, G., Yang, Y., Sun, H., Xu, S., Wang, J., Ahmad, M., \& Xu, Z. (2017). Defective ZnCo ${ }_{2}$ O with Zn vacancies: Synthesis, property and electrochemical application. Journal of Alloys and Compounds, 724, 11491156. https://doi.org/10.1016/j.jallcom.2017.07.136

\section{General rights}

Copyright and moral rights for the publications made accessible in the public portal are retained by the authors and/or other copyright owners and it is a condition of accessing publications that users recognise and abide by the legal requirements associated with these rights.

- Users may download and print one copy of any publication from the public portal for the purpose of private study or research.

- You may not further distribute the material or use it for any profit-making activity or commercial gain

- You may freely distribute the URL identifying the publication in the public portal 


\section{Accepted Manuscript}

Defective $\mathrm{ZnCo}_{2} \mathrm{O}_{4}$ with $\mathrm{Zn}$ vacancies: Synthesis, property and electrochemical application

Guoyong Huang, Yue Yang, Hongyu Sun, Shengming Xu, Junlian Wang, Mashkoor Ahmad, Zhenghe $\mathrm{Xu}$

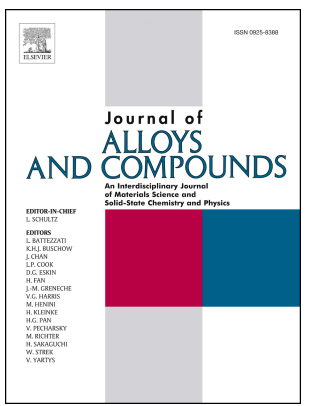

PII: S0925-8388(17)32501-X

DOI: 10.1016/j.jallcom.2017.07.136

Reference: JALCOM 42552

To appear in: Journal of Alloys and Compounds

Received Date: 4 May 2017

Revised Date: 26 June 2017

Accepted Date: 12 July 2017

Please cite this article as: G. Huang, Y. Yang, H. Sun, S. Xu, J. Wang, M. Ahmad, Z. Xu, Defective $\mathrm{ZnCo}_{2} \mathrm{O}_{4}$ with $\mathrm{Zn}$ vacancies: Synthesis, property and electrochemical application, Journal of Alloys and Compounds (2017), doi: 10.1016/j.jallcom.2017.07.136.

This is a PDF file of an unedited manuscript that has been accepted for publication. As a service to our customers we are providing this early version of the manuscript. The manuscript will undergo copyediting, typesetting, and review of the resulting proof before it is published in its final form. Please note that during the production process errors may be discovered which could affect the content, and all legal disclaimers that apply to the journal pertain. 

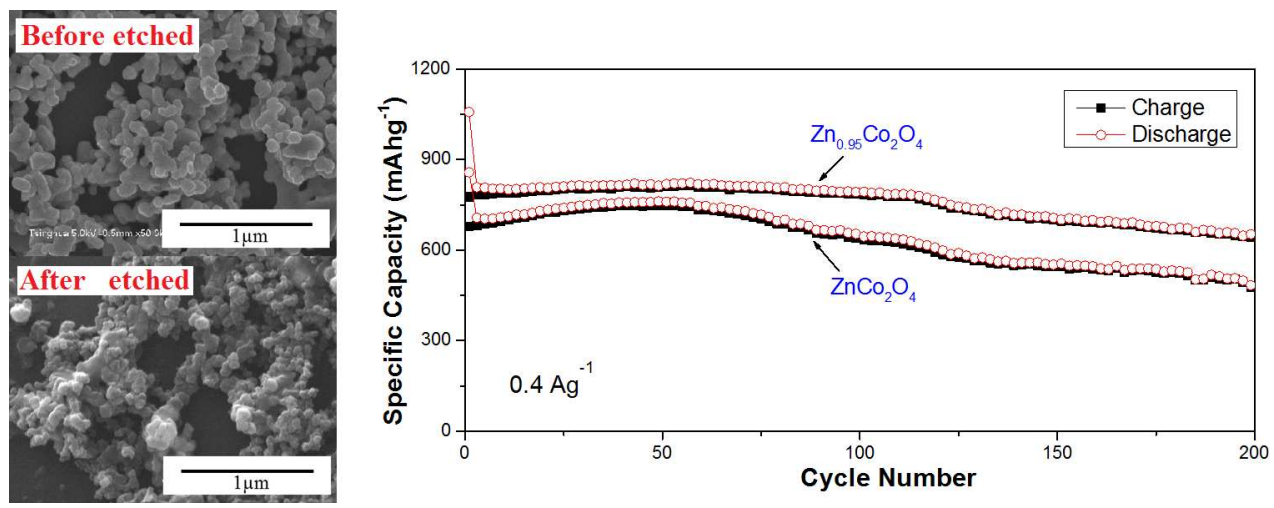


\section{Defective $\mathrm{ZnCo}_{2} \mathrm{O}_{4}$ with $\mathrm{Zn}$ vacancies: synthesis, property and electrochemical application}

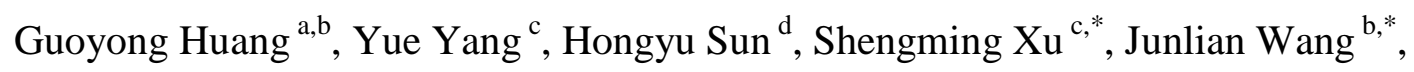
Mashkoor Ahmad ${ }^{\mathrm{e}}$, Zhenghe Xu ${ }^{\mathrm{b}, \mathrm{c}, *}$

${ }^{\text {a }}$ School of Metallurgy and Environment, Central South University, Changsha 410083, China

${ }^{\mathrm{b}}$ Department of Chemical and Materials Engineering, University of Alberta, Edmonton, Alberta T6G 2V4, Canada

${ }^{\mathrm{c}}$ Institute of Nuclear and New Energy Technology, Tsinghua University, Beijing 100084, China

${ }^{\mathrm{d}}$ Department of Micro- and Nanotechnology, Technical University of Denmark, Kongens Lyngby 2800, Denmark

${ }^{\text {e }}$ Nanomaterials Research Group (NRG), Physics Division, PINSTECH, P.O. Nilore, Islamabad 44000, Pakistan

ABSTRACT: Through the liquid-phase co-precipitation and alkaline-tailored method, the defective $\mathrm{ZnCo}_{2} \mathrm{O}_{4}$ with $\mathrm{Zn}$ vacancies $\left(\mathrm{Zn}_{0.95} \mathrm{Co}_{2} \mathrm{O}_{4}\right)$ has been synthesized, which is similar to the crystal phase, morphology, and particle size of the pure $\mathrm{ZnCo}_{2} \mathrm{O}_{4}$ before etched, except the enlarged BET specific surface. For the first time, the $\mathrm{Zn}_{0.95} \mathrm{Co}_{2} \mathrm{O}_{4}$ has been evaluated as an anode material for lithium-ion batteries. The $\mathrm{Zn}$ vacancies in defective $\mathrm{ZnCo}_{2} \mathrm{O}_{4}$ may decrease the probability of the reversible by-reaction between $\mathrm{Zn}$ and $\mathrm{Li}-\mathrm{Zn}$ alloy by the cyclic voltammogram measurement. Compared to the traditional $\mathrm{ZnCo}_{2} \mathrm{O}_{4}$, the $\mathrm{Zn}$ vacancies in defective $\mathrm{ZnCo}_{2} \mathrm{O}_{4}$ can provide larger interface, activate more reaction sites and expand faster transport paths for both of Li-ions and electronics insertion/extraction, so the electrochemical performance of defective $\mathrm{ZnCo}_{2} \mathrm{O}_{4}$ has been enhanced highly. The discharge capacity 
retains at $652.2 \mathrm{mAh} \cdot \mathrm{g}^{-1}$ under $0.4 \mathrm{~A} \cdot \mathrm{g}^{-1}$ after 200 cycles. When the rate returns to 0.4 $\mathrm{Ah} \cdot \mathrm{g}^{-1}$, the average discharge capacity could be recovered to $748.9 \mathrm{mAh} \cdot \mathrm{g}^{-1}$ under the multiple-step high rates after many cycles.

KEYWORDS: $\mathrm{ZnCo}_{2} \mathrm{O}_{4}$, vacancy, defect, nanosheet, anode, energy storage materials

\section{Introduction}

Li-ion batteries (LIBs) with high energy density are considered to apply in energy storage systems (ESSs), hybrid electric vehicles (HEVs) and electric vehicles (EVs) $[1,2]$. But the commercial anode (graphite) of LIBs is the shortest board due to the low theoretical capacity $\left(372 \mathrm{mAh} \cdot \mathrm{g}^{-1}\right)$ and the limited hosts of $\mathrm{Li}$-ion intercalation [3]. So kinds of potential anode materials with higher theoretical capacity have been widely investigated including $\mathrm{Li}_{4} \mathrm{Ti}_{5} \mathrm{O}_{12}, \mathrm{Si}$, graphene, $\mathrm{TiO}_{2}, \mathrm{SnO}_{2}, \mathrm{Co}_{3} \mathrm{O}_{4}, \mathrm{MoS}_{2}$ and so on $[4,5]$. Among them, the transition metal oxides (TMOs) $\left(\mathrm{Co}_{3} \mathrm{O}_{4}, \mathrm{NiO}, \mathrm{CoO}\right.$, $\mathrm{MnO}_{2}$, et al.) have been focused on account of hosting more Li-ions on the conversion reaction [6-11]. However, the practical applications are still hampered by the poor electrical conductivity, high voltage plateaus, and large volume expansion of TMOs $[1,3,4]$. As a result, $\mathrm{ZnCo}_{2} \mathrm{O}$, one of binary TMOs, is considered as an attractive candidate, since $\mathrm{Zn}$ owns good electrochemical activity for Li-ion insertion/extraction [12-17]. Thus far, kinds of $\mathrm{ZnCo}_{2} \mathrm{O}_{4}$ materials and composites have been prepared via kinds of methods as follows. Through a solvothermal self-assembling process, flower-like porous $\mathrm{ZnCo}_{2} \mathrm{O}_{4}$ microspheres (1.0-1.2 $\mu \mathrm{m}$ ) delivers a high reversible specific capacity of $940 \mathrm{mAh} \cdot \mathrm{g}^{-1}$ after 100 cycles at $0.1 \mathrm{~A} \cdot \mathrm{g}^{-1}[15] . \mathrm{ZnCo}_{2} \mathrm{O}_{4} / \mathrm{graphene}$ 
has been prepared via a urea-assisted auto-combustion method with an enhanced rate capability of $378.1 \mathrm{mAh} \cdot \mathrm{g}^{-1}$ at $4.5 \mathrm{C}$ [16]. Self-supported $\mathrm{ZnO} / \mathrm{ZnCo}_{2} \mathrm{O}_{4}$ submicron rod arrays on Ni foil by an ammonia-evaporation-induced method have improved the Li-ion transfer and electrolyte permeability [17]. $\mathrm{ZnCo}_{2} \mathrm{O}_{4} @ \mathrm{C}$ with 3D porous wrinkled-paper-like structure via a hydrothermal method has shown a fair cycling property [18]. Yolk-shell $\mathrm{ZnCo}_{2} \mathrm{O}_{4}$ through an ultrasonic spray pyrolysis has possessed a reasonable structure and heat stability at $60{ }^{\circ} \mathrm{C}$ under $3 \mathrm{~A} \cdot \mathrm{g}^{-1}$ after 200 cycles [19]. Nevertheless, the electrochemical performance of $\mathrm{ZnCo}_{2} \mathrm{O}_{4}$, especially the rate capacity and the cycling stability, should be further developed.

Remarkably, defects and particular vacancies at metal oxides (MOs) play an important role in a variety of applications $[20,21]$. These vacancies may be considered to be reactive agents, adsorption sites, electron donor sites, or small metal clusters, which directly influence electronic structure, charge transport, surface steady, and optoelectronic reactivity [21]. By annealing in an appropriate atmosphere, single-crystalline $\mathrm{ZnO}$ samples with $\mathrm{Zn}$ or $\mathrm{O}$ vacancies could affect the near band edge (NBE) signals directly [22]. And defective $\mathrm{TiO}_{2}$ with $\mathrm{O}$ vacancies via air plasma treatment is intimately related to the optical absorption region/red shift (from 3.22 to $3.00 \mathrm{eV})[23,24]$. In addition, the defect adjustment can regulate effectively the electronic properties of different catalysts. For example, $\mathrm{Co}_{3} \mathrm{O}_{4}$ with $\mathrm{O}$ vacancies on the surface is an enhanced catalyst for ethylene hydrogenation [25]; and $\mathrm{MnO}_{2}$ via adjusting Mn Vacancies has a dramatic catalytic reaction active for HCHO oxidation [26]. So it is necessary to realize the distinct relationship between the $\mathrm{Zn}$ vacancies in 
$\mathrm{ZnCo}_{2} \mathrm{O}_{4}$ and the electrochemical performance. Hopefully, the research would stimulate the interest in the development of TMOs with defects.

Herein, novel defective $\mathrm{ZnCo}_{2} \mathrm{O}_{4}$ with $\mathrm{Zn}$ vacancies has been designed and prepared successfully by alkaline-tailored method at low temperature. To the best of our knowledge, this is the first report on the electrochemical performance of defective $\mathrm{ZnCo}_{2} \mathrm{O}_{4}$ with $\mathrm{Zn}$ vacancies. Evaluated as an anode material for LIBs and compared with the similar normal $\mathrm{ZnCo}_{2} \mathrm{O}_{4}$, the exceptional electrochemical performance including higher rate capability and better capacity retention is identified. And the finding may reveal an innovative method to enhance the electrochemical activity of TMOs via vacancies. The details are further discussed below.

\section{Experimental Section}

Materials. All reagents including $\mathrm{CoSO}_{4} \bullet 7 \mathrm{H}_{2} \mathrm{O}$ (molecular weight 281.10), $\mathrm{ZnSO}_{4} \cdot 7 \mathrm{H}_{2} \mathrm{O}$ (molecular weight 287.56), $\mathrm{NaOH}$ (molecular weight 40.00 ), Tween-40 (Polyoxyethylene 40 sorbitan monopalmitate, molecular weight 1283.62) are the analytical grade.

Materials Preparation. The method of $\mathrm{ZnCo}_{2} \mathrm{O}_{4}$ precursor (mixture of $\mathrm{Co}(\mathrm{OH})_{2}$ and $\left.\mathrm{Zn}(\mathrm{OH})_{2}\right)$ by liquid-phase co-precipitation was similar to our previous work [27-29]. As a typical synthesis, $\mathrm{CoSO}_{4} \bullet 7 \mathrm{H}_{2} \mathrm{O}(2.8110 \mathrm{~g})$ and $\mathrm{ZnSO}_{4} \bullet 7 \mathrm{H}_{2} \mathrm{O}(2.876 \mathrm{~g})$ were dissolved in deionized water to form a $100 \mathrm{~mL}$ homogeneous solution (Solution A); while $\mathrm{NaOH}(0.800 \mathrm{~g})$ as a precipitation agent and Tween-40 (0.010 g) as a dispersing agent were dissolved in deionized water to form the other $100 \mathrm{~mL}$ homogeneous solution (Solution B). In order to adjust the $\mathrm{pH}$ value to 10.0 11.0, an 
appropriate amount of $\mathrm{NaOH}$ was added to $50 \mathrm{~mL}$ deionized water (Solution $\mathrm{C}$ ), which was transferred into a $500 \mathrm{~mL}$ flask as mother liquor firstly. Both Solution A and Solution B were added dropwise into this flask under stirring at $25{ }^{\circ} \mathrm{C}$; while the $\mathrm{pH}$ value of reaction system was controlled at 10.0 11.0 through adding a little saturated $\mathrm{NaOH}$ solution. The liquid-phase reaction was kept on $30 \mathrm{~min}$, and the pink precipitate as a $\mathrm{ZnCo}_{2} \mathrm{O}_{4}$ precursor was obtained. After washed by deionized water and dried in a vacuum oven at $40{ }^{\circ} \mathrm{C}$, the precursor was thermally treated at $450{ }^{\circ} \mathrm{C}$ in air for $6 \mathrm{~h}$ with the ramp of $5{ }^{\circ} \mathrm{C} \cdot \mathrm{min}^{-1}$. Subsequently, the black $\mathrm{ZnCo}_{2} \mathrm{O}_{4}$ sample was prepared. At last, $\mathrm{NaOH}$ (16.000 g) was dissolved in deionized water to form a 200 mL homogeneous solution (Solution D), which was transferred into a $400 \mathrm{~mL}$ beaker as the alkaline etchant. And all of the above $\mathrm{ZnCo}_{2} \mathrm{O}_{4}$ powders were added into the beaker under stirring at $25^{\circ} \mathrm{C}$, and the etching reaction was kept on $1 \mathrm{~h}$. After washed by deionized water and dried in a vacuum oven at $40{ }^{\circ} \mathrm{C}$ for $24 \mathrm{~h}$, the defective $\mathrm{ZnCo}_{2} \mathrm{O}_{4}$ sample was synthesized.

Materials Characterization. The elemental analysis was characterized by inductively coupled plasma atomic emission spectroscopy (ICP-AES) (Baird, PS-6). The thermal behavior was analyzed by thermogravimetric analysis (TGA) (Netzsch, 409PC) in air atmosphere with temperature range from $30{ }^{\circ} \mathrm{C}$ to $800{ }^{\circ} \mathrm{C}$ at ramp rate of $5{ }^{\circ} \mathrm{C} \cdot \mathrm{min}^{-1}$. The XRD patterns were recorded by X-ray powder diffraction (XRD) (Rigaku, D/Max-2000). The nitrogen adsorption data were calculated by Nitrogen adsorption data (Quantachrome, Autosorb-iQ). The X-ray photoelectron spectroscopy (XPS) characterization was carried out by an ESCALAB 250 instrument. The micro 
morphological and structural characterization was investigated by scanning electron microscope (SEM) (TESCAN, MIRA3 and JEOL), atomic force microscope (AFM) (Bruker, Dimension Icon) and transmission electron microscope (TEM) (FEI, Tecnai G2 F20).

Electrochemical Measurements. All of electrochemical measurements were similar to our previous work including the type of coin cell, the composition of working electrode, the weight of active material, the electrolyte and so on [30-32]. The galvanostatic cycling test was conducted at $25{ }^{\circ} \mathrm{C}$ under different rates by battery chargers (Land, CT2001A). Using the electrochemical workstation (Metrohm, Autolab), the cyclic voltammogram (CV) test was performed under the scan rate of $0.1 \mathrm{mV} \cdot \mathrm{s}^{-1}$ between $0.01 \mathrm{~V}$ and $3.00 \mathrm{~V}\left(v s . \mathrm{Li}^{+} / \mathrm{Li}\right)$, and the electrochemical impedance spectroscopy (EIS) was carried out at AC voltage of $5 \mathrm{mV}$ amplitude under the open-circuit condition over a frequency range of $1.00 \mathrm{MHz}$ to $0.01 \mathrm{~Hz}$.

\section{Results and Discussion}

The as-prepared $\mathrm{ZnCo}_{2} \mathrm{O}_{4}$ precursor by simple liquid-phase co-precipitation is studied by XRD to confirm the crystalline phase [Eq. (1)]. As shown in Fig. S1 (Supporting Information), the main diffraction peaks correspond to the mixture of $\mathrm{Co}(\mathrm{OH})_{2}$ (JCPDS no.30-0443) and $\mathrm{Zn}(\mathrm{OH})_{2}$ (JCPDS no.20-1437). And the typical morphology of precursor is irregular nano-particles shown in the Fig. S2 (Supporting Information). In order to gain the best heating treatment temperature of $\mathrm{ZnCo}_{2} \mathrm{O}_{4}$, the thermal behavior of precursor is characterized by TGA at air atmosphere shown in Fig. 1. The TGA curve exhibits two distinct weight loss steps. The first weight loss 
between $30{ }^{\circ} \mathrm{C}$ and $146{ }^{\circ} \mathrm{C}$ is $\sim 2.0 \%$, which may be assigned to the evaporation of moisture. And the second weight loss between $146^{\circ} \mathrm{C}$ and $398^{\circ} \mathrm{C}$ is $\sim 12.3 \%$, which may be attributed to the transformation of $\mathrm{M}(\mathrm{OH})_{2}(\mathrm{M}=\mathrm{Co}$ and $\mathrm{Zn})$ into $\mathrm{ZnCo}_{2} \mathrm{O}_{4}$ [Eq. (2)]. After $398{ }^{\circ} \mathrm{C}$, almost no weight loss appears. Hence, in the corresponding $\mathrm{ZnCo}_{2} \mathrm{O}_{4}$ synthesis, the thermal treatment temperature is controlled at $450{ }^{\circ} \mathrm{C}$.

$$
\begin{aligned}
& \mathrm{M}^{2+}+2 \mathrm{OH}^{-} \rightarrow \mathrm{M}(\mathrm{OH})_{2} \downarrow \quad(\mathrm{M}=\mathrm{Co} \text { and } \mathrm{Zn}) \\
& 4 \mathrm{Co}(\mathrm{OH})_{2}+2 \mathrm{Zn}(\mathrm{OH})_{2}+\mathrm{O}_{2} \rightarrow 2 \mathrm{ZnCo}_{2} \mathrm{O}_{4}+6 \mathrm{H}_{2} \mathrm{O}
\end{aligned}
$$

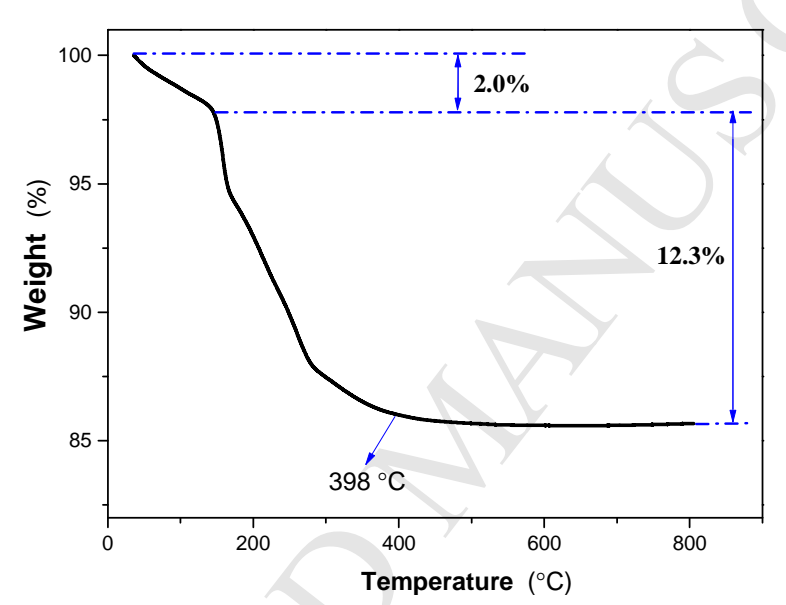

Fig. 1 TGA curve of as-prepared $\mathrm{ZnCo}_{2} \mathrm{O}_{4}$ precursor under air atmosphere $\left(5^{\circ} \mathrm{C} \cdot \mathrm{min}^{-1}\right)$

Generally, in strong alkaline solution, $\mathrm{Zn}^{2+}$ in the solid-phase could react with $\mathrm{OH}^{-}$ to form soluble $\mathrm{Zn}(\mathrm{OH})_{4}{ }^{2-}[33,34]$. Base on the mechanism, a handful of $\mathrm{Zn}$-ions in $\mathrm{ZnCo}_{2} \mathrm{O}_{4}$ particles are etched through this alkaline-tailored method at low temperature, so the pure $\mathrm{ZnCo}_{2} \mathrm{O}_{4}$ is transformed into the defective $\mathrm{ZnCo}_{2} \mathrm{O}_{4}$ with $\mathrm{Zn}$ vacancies. Measured by ICP-AES, the Mole ratio of $\mathrm{Zn}$ and $\mathrm{Co}$ is $0.95: 2.00$ in the defective $\mathrm{ZnCo}_{2} \mathrm{O}_{4}$, so its molecular formula can be recorded as $\mathrm{Zn}_{0.95} \mathrm{Co}_{2} \mathrm{O}_{4}$. In addition, Na, $\mathrm{Fe}, \mathrm{Ca}$ and $\mathrm{Mg}$ contents of the $\mathrm{Zn}_{0.95} \mathrm{Co}_{2} \mathrm{O}_{4}$ sample are $58 \mathrm{ppm}, 13 \mathrm{ppm}, 22 \mathrm{ppm}$ and 18 ppm, respectively. And Fig. 2 shows the phase purity of $\mathrm{ZnCo}_{2} \mathrm{O}_{4}$ powders before and after etched. Both of the diffraction peaks match well with the spinel $\mathrm{ZnCo}_{2} \mathrm{O}_{4}$ 
(JCPDS no.23-1390), which locate at 2 theta of $18.94^{\circ}, 31.25^{\circ}, 36.82^{\circ}, 38.60^{\circ}, 44.81^{\circ}$, $55.50^{\circ}, 59.28^{\circ}, 65.23^{\circ}$ and $77.30^{\circ}$ corresponding to (111), (220), (311), (222), (400), (422), (511), (440) and (533), respectively. Hence, it indicates that the etch treatment does not affect the crystal structure of $\mathrm{ZnCo}_{2} \mathrm{O}_{4}$. In addition, The BET specific surface area of $\mathrm{ZnCo}_{2} \mathrm{O}_{4}$ is measured to $105.07 \mathrm{~m}^{2} \cdot \mathrm{g}^{-1}$; after etched, the corresponding specific surface area of defective $\mathrm{ZnCo}_{2} \mathrm{O}_{4}$ increases to $170.12 \mathrm{~m}^{2} \cdot \mathrm{g}^{-1}$, which is probably caused by the additional interface due to $\mathrm{Zn}$ vacancies in nano-particles (Fig. $3)$.

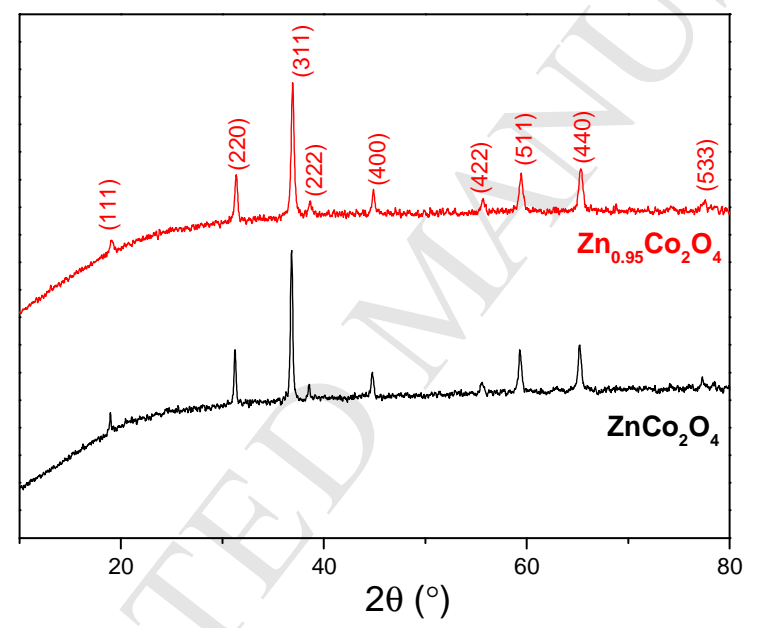

Fig. 2 XRD patterns of $\mathrm{ZnCo}_{2} \mathrm{O}_{4}$ and $\mathrm{Zn}_{0.95} \mathrm{Co}_{2} \mathrm{O}_{4}$

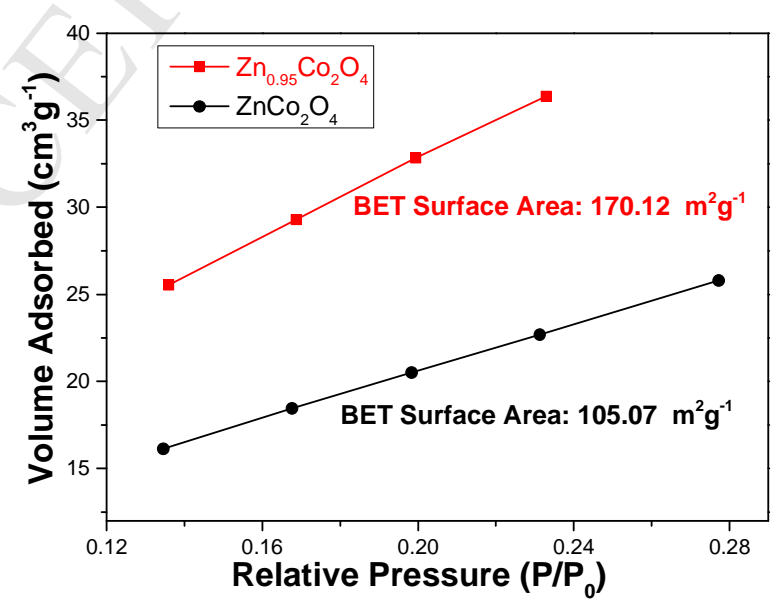

Fig. $3 \mathrm{~N}_{2}$ adsorption isotherms of $\mathrm{ZnCo}_{2} \mathrm{O}_{4}$ and $\mathrm{Zn}_{0.95} \mathrm{Co}_{2} \mathrm{O}_{4}$

Morphology and micro-structure of as-synthesized samples are characterized by 
the SEM technique in Fig. 4. Figs. $4 \mathrm{a}$ and $4 \mathrm{~b}$ clearly display the typical irregular lamellar structure of $\mathrm{ZnCo}_{2} \mathrm{O}_{4}$ with good dispersion, and the particle size of $\mathrm{ZnCo}_{2} \mathrm{O}_{4}$ nanosheets is $50-200 \mathrm{~nm}$. Figs. 4c shows that the morphology and particle size of $\mathrm{Zn}_{0.95} \mathrm{Co}_{2} \mathrm{O}_{4}$ keep similar to the above $\mathrm{ZnCo}_{2} \mathrm{O}_{4}$ powders, which proves that the etch treatment does not damage the micro-structure of nano-particles. The higher-magnification SEM image (Fig.4d) elucidates that the $\mathrm{Zn}_{0.95} \mathrm{Co}_{2} \mathrm{O}_{4}$ nanosheets pile up obviously, and the phenomenon of agglomeration is more serious than the $\mathrm{ZnCo}_{2} \mathrm{O}_{4}$ powders', which may be attributed to the additional specific surface energy by the etch treatment. Further information about the $\mathrm{Zn}_{0.95} \mathrm{Co}_{2} \mathrm{O}_{4}$ nanosheets is obtained form TEM and high-resolution TEM (HRTEM) images. Nanosheets with diameter of 50-200 $\mathrm{nm}$ touched each other is clearly observed again in Fig. 5a. In Figs. $5 b-5 d$, all of the lattice fringes are uniform, and the corresponding interplanar spacings of $0.24 \mathrm{~nm}, 0.29 \mathrm{~nm}$ and $0.20 \mathrm{~nm}$ are indexed to the (311), (220) and (400) planes of spinel $\mathrm{ZnCo}_{2} \mathrm{O}_{4}$ phase, respectively. Remarkably, the thin layered structure of $\mathrm{Zn}_{0.95} \mathrm{Co}_{2} \mathrm{O}_{4}$ particles are further confirmed by the AFM image (Fig. 6); and the thickness of $\mathrm{Zn}_{0.95} \mathrm{Co}_{2} \mathrm{O}_{4}$ nanosheets is measured to $10-12 \mathrm{~nm}$. What is more, in order to understand the surface electronic states of $\mathrm{Zn}_{0.95} \mathrm{Co}_{2} \mathrm{O}_{4}$ particles, the XPS analysis is also carried out in Fig. 7. The full wide-scan spectrum shows the presence of $\mathrm{Zn}$, Co, $\mathrm{O}$ and $\mathrm{C}$ in Fig. 7a (C 1s line is used as the reference for calibration). And the two peaks at the binding energies of $1020.4 \mathrm{eV}$ and $1043.5 \mathrm{eV}$ are associated with $\mathrm{Zn} 2 \mathrm{p}_{3 / 2}$ and $\mathrm{Zn} 2 \mathrm{p}_{1 / 2}$ of $\mathrm{Zn}^{2+}$ in Fig. $7 \mathrm{~b}$; while the major peaks at $779.6 \mathrm{eV}$ and $794.5 \mathrm{eV}$ with a spin-orbit splitting of $15.1 \mathrm{eV}$ are attributed to Co $2 \mathrm{p}_{3 / 2}$ and Co $2 \mathrm{p}_{1 / 2}$ in Fig. $7 \mathrm{c}$, 
confirming the presence of $\mathrm{Co}^{2+}$ and $\mathrm{Co}^{3+}[35-37]$. The XPS results demonstrate that the surface $\mathrm{Zn}$ and $\mathrm{Co}$ cation valences of $\mathrm{Zn}_{0.95} \mathrm{Co}_{2} \mathrm{O}_{4}$ after etched are the same as the traditional $\mathrm{ZnCo}_{2} \mathrm{O}_{4}[16-19]$.

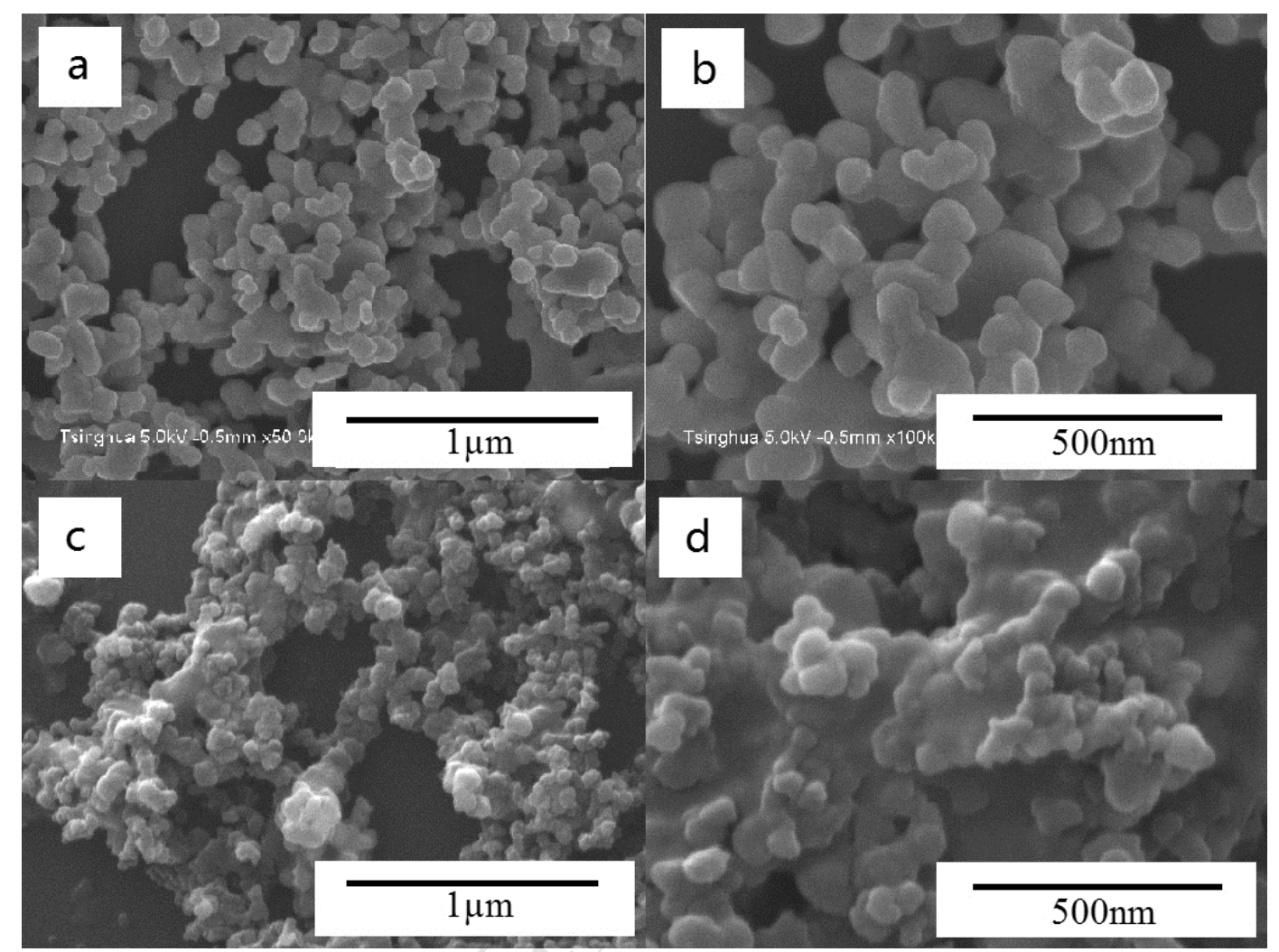

Fig. 4 (a), (b) SEM images of $\mathrm{ZnCo}_{2} \mathrm{O}_{4}$ powders and (c), (d) SEM images of $\mathrm{Zn}_{0.95} \mathrm{Co}_{2} \mathrm{O}_{4}$ powders 


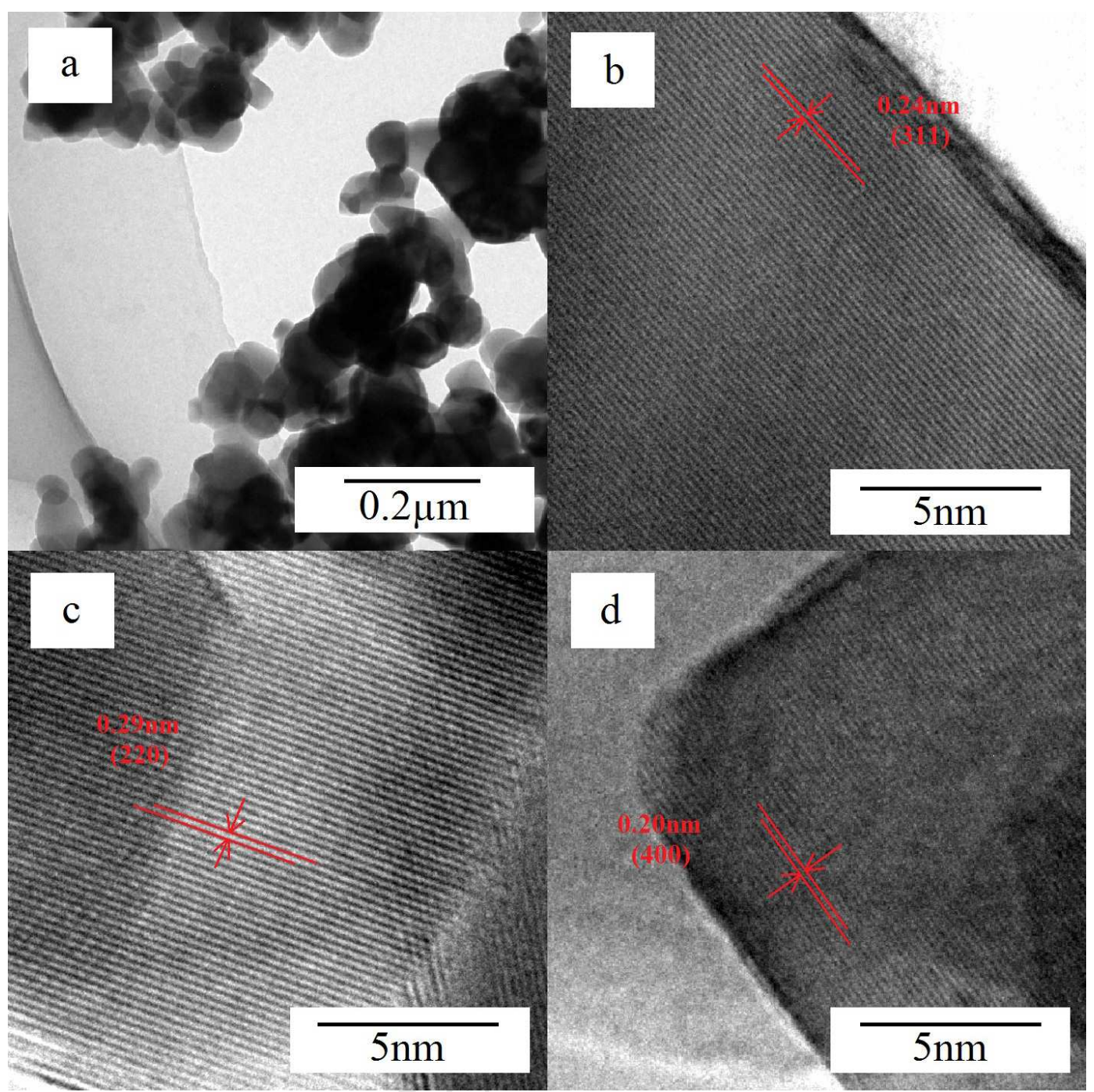

Fig. 5 (a) TEM and (b)-(d) HRTEM images of $\mathrm{Zn}_{0.95} \mathrm{Co}_{2} \mathrm{O}_{4}$ powders

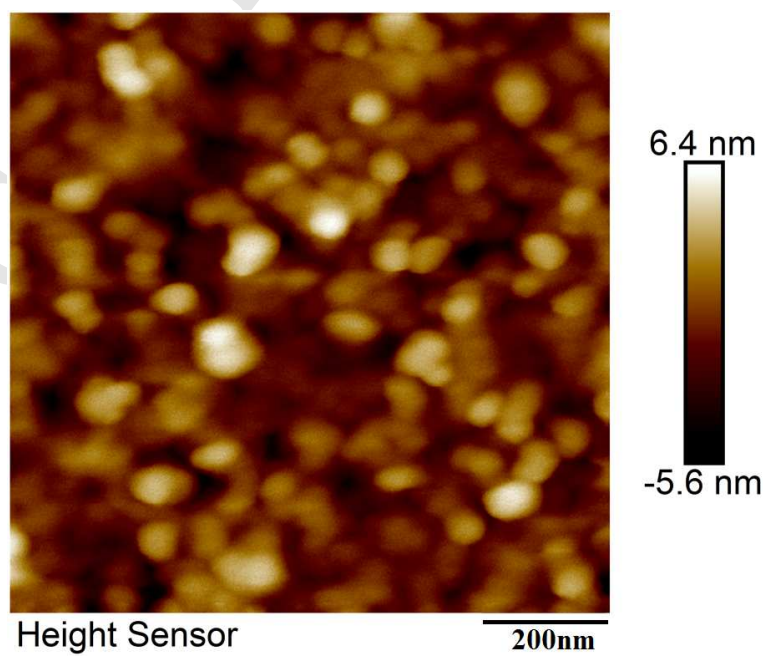

Fig. 6 AFM image of $\mathrm{Zn}_{0.95} \mathrm{Co}_{2} \mathrm{O}_{4}$ powders 

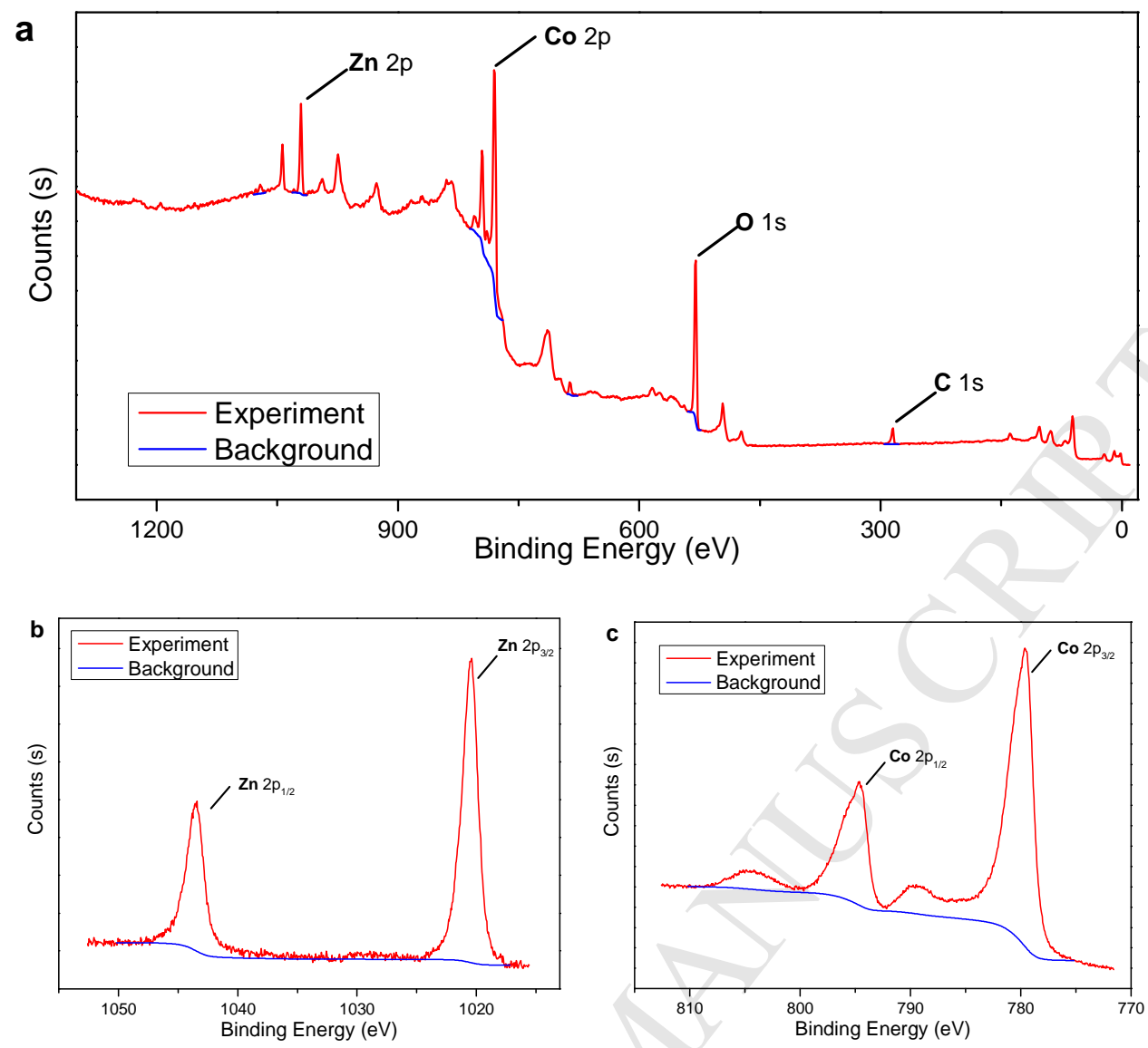

Fig. 7 XPS spectra of $\mathrm{Zn}_{0.95} \mathrm{Co}_{2} \mathrm{O}_{4}$

To further understand the reaction mechanism of $\mathrm{Zn}_{0.95} \mathrm{Co}_{2} \mathrm{O}_{4}$ electrode, the $\mathrm{CV}$ curves between $0.01 \mathrm{~V}$ and $3.00 \mathrm{~V}\left(v s . \mathrm{Li}^{+} / \mathrm{Li}\right)$ at $0.1 \mathrm{mV} \cdot \mathrm{s}^{-1}$ is conducted for the initial five cycles in Fig. 8. In the 1st cathodic sweep, an well-defined reduction peak is recorded at $\sim 0.78 \mathrm{~V}$, which may be attributed to the intercalation of Li-ions into the spinel structure and the reduction of $\mathrm{Zn}_{0.95} \mathrm{Co}_{2} \mathrm{O}_{4}$ to $\mathrm{Zn}$ and $\mathrm{Co}$ (Mole ratio of $\mathrm{Zn}: \mathrm{Co}=$ 0.95:2) [Eq. (3)]; and a broad anodic peak is observed at $\sim 2.15 \mathrm{~V}$ due to the oxidations of $\mathrm{Zn} /$ defective $\mathrm{ZnO}$ and $\mathrm{Co} / \mathrm{CoO}$ [Eq. (4)] [38-41]. In the subsequent cathodic sweep, the reduction peak is moved to $\sim 1.00 \mathrm{~V}$ and becomes broader than the 1st cycle, which belongs to the other reductions of defective $\mathrm{ZnO} / \mathrm{Zn}$ and $\mathrm{CoO} / \mathrm{Co}$ [Eq. (5)]. From the 2nd cycle onwards, the CV curves almost remain overlapped, which implies the high reversibility of electrochemical reactions and excellent kinetic 
of $\mathrm{Zn}_{0.95} \mathrm{Co}_{2} \mathrm{O}_{4}$ for $\mathrm{Li}$-ions insertion/extraction. In addition, compared to the traditional $\mathrm{ZnCo}_{2} \mathrm{O}_{4}[42,43]$, the peaks indexed to the reversible reaction of $\mathrm{Zn}$ and $\mathrm{Li}-\mathrm{Zn}$ alloy is not observed in this research, so the $\mathrm{Zn}$ vacancies in defective $\mathrm{ZnCo}_{2} \mathrm{O}_{4}$ may decrease the probability of the by-reaction.

$$
\begin{aligned}
& \mathrm{Zn}_{0.95} \mathrm{Co}_{2} \mathrm{O}_{4}+8 \mathrm{Li}^{+}+8 \mathrm{e}^{-} \rightarrow 0.95 \mathrm{Zn}+2 \mathrm{Co}+4 \mathrm{Li}_{2} \mathrm{O} \\
& 0.95 \mathrm{Zn}+2 \mathrm{Co}+3 \mathrm{Li}_{2} \mathrm{O} \rightarrow \mathrm{Zn}_{0.95} \mathrm{O}+2 \mathrm{CoO}+6 \mathrm{Li}^{+}+6 \mathrm{e}^{-} \\
& \mathrm{Zn}_{0.95} \mathrm{O}+2 \mathrm{CoO}+6 \mathrm{Li}^{+}+6 \mathrm{e}^{-} \rightarrow 0.95 \mathrm{Zn}+2 \mathrm{Co}+3 \mathrm{Li}_{2} \mathrm{O}
\end{aligned}
$$

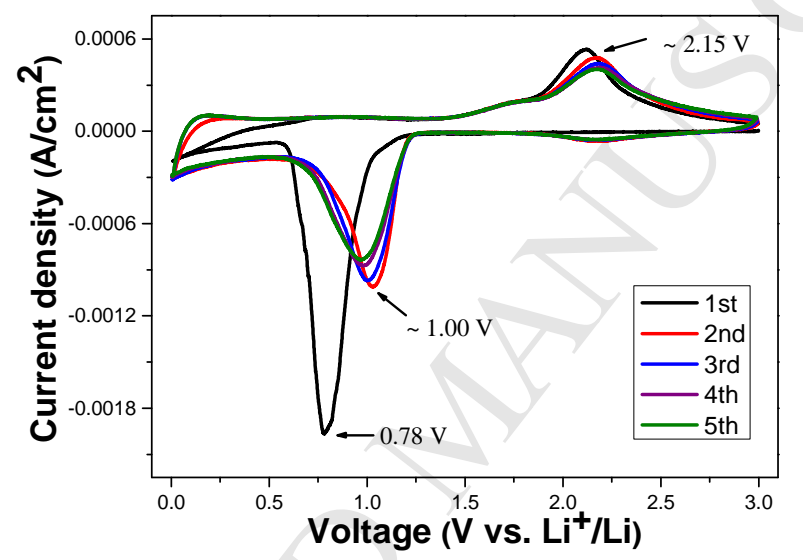

Fig. 8 First five cyclic voltammogram curves of $\mathrm{Zn}_{0.95} \mathrm{Co}_{2} \mathrm{O}_{4}$ electrode at a scan rate of 0.1 $\mathrm{mV} \cdot \mathrm{s}^{-1}$ in the range of $0.01-3.00 \mathrm{~V}$

The plots of specific capacity $v s$. voltage at $0.4 \mathrm{~A} \cdot \mathrm{g}^{-1}$ with different cycles are shown in Fig. 9. An evident long plateaus in every discharge curve exhibits at $\sim 1.0 \mathrm{~V}$, and an unobvious short plateaus in every charge curve presents between 1.9 2.2 V, which match well with the above $\mathrm{CV}$ results. The initial discharge and charge process are up to $1057.0 \mathrm{mAh} \cdot \mathrm{g}^{-1}$ and $776.3 \mathrm{mAh} \cdot \mathrm{g}^{-1}$, respectively, corresponding to a Coulombic efficiency (CE) of $73.4 \%$. The irreversible capacity loss may come from the consumption of active materials in the formation of the SEI film and the irreversible reaction [Eq. (3)], which is reflected in the above CV profiles, too [44,45]. Subsequently, the 50th and 100th CEs are high to $99.5 \%$ and $98.6 \%$, respectively, 
demonstrating the super stability of defective $\mathrm{ZnCo}_{2} \mathrm{O}_{4}$ and the fast transport paths of Li-ions insertion/extraction due to the $\mathrm{Zn}$ vacancies again.

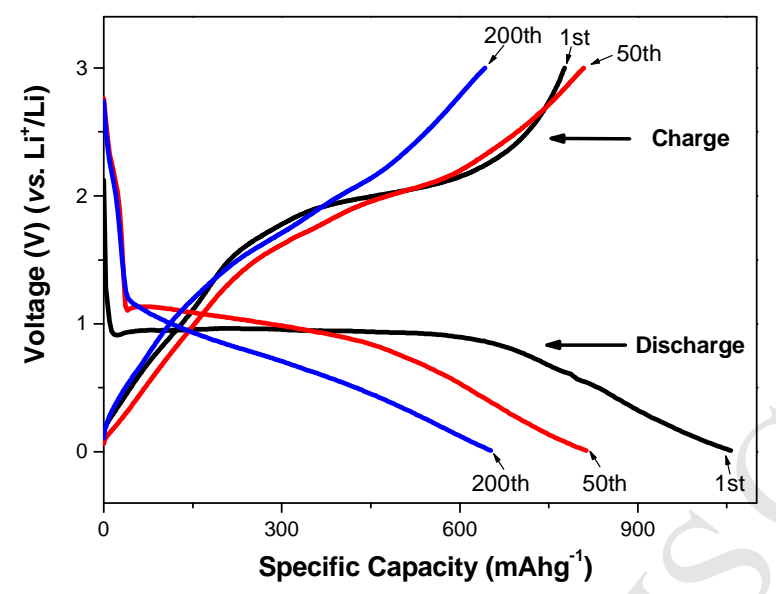

Fig. 9 Different discharge and charge profiles of $\mathrm{Zn}_{0.95} \mathrm{Co}_{2} \mathrm{O}_{4}$ electrode in the range of 0.01-3.00 $\mathrm{V}$ at $0.4 \mathrm{~A} \cdot \mathrm{g}^{-1}$

The cycling performance of the $\mathrm{Zn}_{0.95} \mathrm{Co}_{2} \mathrm{O}_{4}$ after etched and the pure $\mathrm{ZnCo}_{2} \mathrm{O}_{4}$ before etched as the reference is displayed in Fig. 10a. At the high rate of $0.4 \mathrm{~A} \cdot \mathrm{g}^{-1}$, the discharge/charge capacity of $\mathrm{Zn}_{0.95} \mathrm{Co}_{2} \mathrm{O}_{4}$ stays very stable and remains at a high value between $805.0 / 800.0 \mathrm{mAh} \cdot \mathrm{g}^{-1}$ and $795.0 / 785.0 \mathrm{mAh} \cdot \mathrm{g}^{-1}$ from the 2 nd cycle to the 100th cycle; then, it begins to fade slowly to $652.2 / 642.5 \mathrm{mAh} \cdot \mathrm{g}^{-1}$ at the $200 \mathrm{th}$ cycle. In comparison, the discharge/charge capacities of pure $\mathrm{ZnCo}_{2} \mathrm{O}_{4}$ are lower than the above $\mathrm{Zn}_{0.95} \mathrm{Co}_{2} \mathrm{O}_{4}$ 's at the same cycle obviously, which suggests that the $\mathrm{Zn}$ vacancies may activate more reaction sites efficiently [46]. And the discharge/charge capacity rises up gradually from $707.1 / 688.0 \mathrm{mAh} \cdot \mathrm{g}^{-1}$ to $760.4 / 750.4 \mathrm{mAh} \cdot \mathrm{g}^{-1}$ at the 2nd 27th cycle, corresponding to the traditional activation process of Li-ion diffusion [47]. Further prolonged cycling to the 200th cycle, it decreases to $483.2 / 476.3$ $\mathrm{mAh} \cdot \mathrm{g}^{-1}$ quickly. It is noted that the cycling stability of defective $\mathrm{ZnCo}_{2} \mathrm{O}_{4}$ with $\mathrm{Zn}$ vacancies is substantially enhanced. 
The rate capabilities are evaluated by a multiple-step galvanostatic strategy at various current densities of $0.6 \sim 6.0 \mathrm{Ah} \cdot \mathrm{g}^{-1}$ in Fig. 10b. At $0.6 \mathrm{Ah} \cdot \mathrm{g}^{-1}$ and $1.0 \mathrm{Ah} \cdot \mathrm{g}^{-1}$, the property of $\mathrm{Zn}_{0.95} \mathrm{Co}_{2} \mathrm{O}_{4}$ and $\mathrm{ZnCo}_{2} \mathrm{O}_{4}$ are similar. The former average discharge/charge capacities except the $1 \mathrm{st}$ cycle are $618.0 / 608.3 \mathrm{mAh} \cdot \mathrm{g}^{-1}$ and 561.8/557.5 $\mathrm{mAh} \cdot \mathrm{g}^{-1}$; while the latter's capacities are $578.3 / 562.6 \mathrm{mAh} \cdot \mathrm{g}^{-1}$ and $534.7 / 523.5 \mathrm{mAh} \cdot \mathrm{g}^{-1}$. When the rate increases to $1.6 \mathrm{Ah} \cdot \mathrm{g}^{-1}, 2.0 \mathrm{Ah} \cdot \mathrm{g}^{-1}$ and $4.0 \mathrm{Ah} \cdot \mathrm{g}^{-1}$, the rate behavior of $\mathrm{Zn}_{0.95} \mathrm{Co}_{2} \mathrm{O}_{4}$ illustrates much better than the $\mathrm{ZnCo}_{2} \mathrm{O}_{4}$ 's. And the corresponding average discharge/charge capacities of $\mathrm{Zn}_{0.95} \mathrm{Co}_{2} \mathrm{O}_{4}$ are 483.5/480.2 $\mathrm{mAh} \cdot \mathrm{g}^{-1}$ and $340.0 / 333.2 \mathrm{mAh} \cdot \mathrm{g}^{-1}, 158.2 / 152.6 \mathrm{mAh} \cdot \mathrm{g}^{-1}$, respectively; in contrast, the latter's capacities are $377.6 / 362.4 \mathrm{mAh} \cdot \mathrm{g}^{-1}, 179.8 / 175.0 \mathrm{mAh} \cdot \mathrm{g}^{-1}$ and $44.7 / 40.5$ $\mathrm{mAh} \cdot \mathrm{g}^{-1}$, respectively. Even at the highest current density of $6.0 \mathrm{Ah} \cdot \mathrm{g}^{-1}$, both of them may lose the cycling ability. Remarkably, when the rate finally returns to $1.0 \mathrm{Ah} \cdot \mathrm{g}^{-1}$, $0.6 \mathrm{Ah} \cdot \mathrm{g}^{-1}$ and $0.4 \mathrm{Ah} \cdot \mathrm{g}^{-1}$ after many cycles at high rates, the average discharge capacities of $\mathrm{Zn}_{0.95} \mathrm{Co}_{2} \mathrm{O}_{4}$ are recovered to $594.9 / 592.8 \mathrm{mAh} \cdot \mathrm{g}^{-1}, 654.2 / 645.5 \mathrm{mAh} \cdot \mathrm{g}^{-1}$ and 748.9/742.1 $\mathrm{mAh} \cdot \mathrm{g}^{-1}$, respectively; however, the corresponding latter's capacities are just restored to $388.4 / 380.2 \mathrm{mAh} \cdot \mathrm{g}^{-1}, 475.1 / 462.2 \mathrm{mAh} \cdot \mathrm{g}^{-1}$ and $543.0 / 532.2$ $\mathrm{mAh} \cdot \mathrm{g}^{-1}$, respectively. Hence, compared to pure $\mathrm{ZnCo}_{2} \mathrm{O}_{4}$, the $\mathrm{Zn}_{0.95} \mathrm{Co}_{2} \mathrm{O}_{4}$ with larger interface area and more $\mathrm{Li}^{+}$insertion/extraction sites may facilitate faster $\mathrm{Li}$-ion transfer between electrolyte and electrode. 

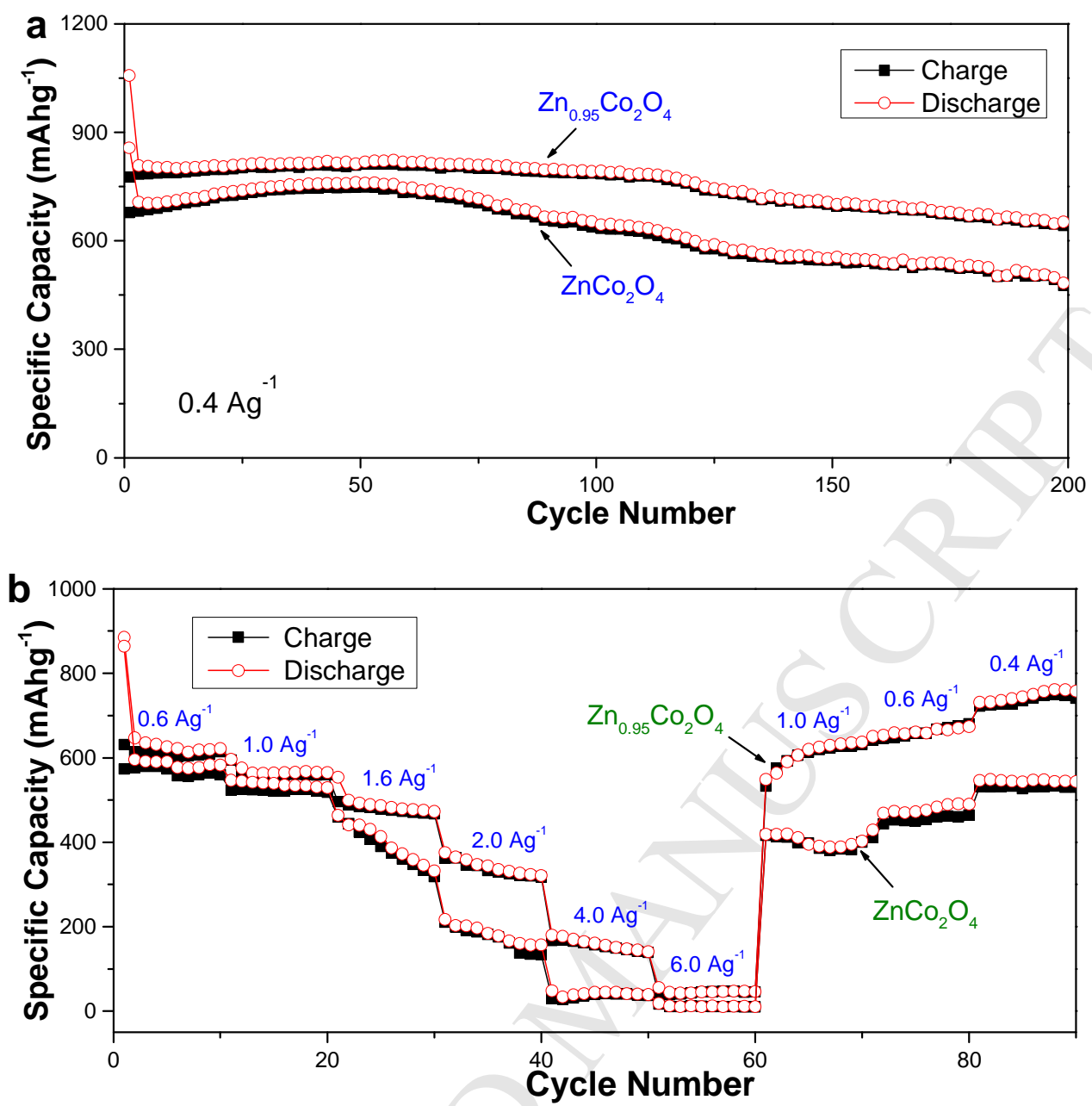

Fig. 10 (a) Cycling performance of $\mathrm{Zn}_{0.95} \mathrm{Co}_{2} \mathrm{O}_{4}$ and $\mathrm{ZnCo}_{2} \mathrm{O}_{4}$ electrodes at $0.4 \mathrm{~A} \cdot \mathrm{g}^{-1}$ and (b) rate performance of $\mathrm{Zn}_{0.95} \mathrm{Co}_{2} \mathrm{O}_{4}$ electrode at different current densities

The EIS curves are tested to confirm the different kinetic process of $\mathrm{Zn}_{0.95} \mathrm{Co}_{2} \mathrm{O}_{4}$ and $\mathrm{ZnCo}_{2} \mathrm{O}_{4}$ after 200 cycles at $0.4 \mathrm{~A} \cdot \mathrm{g}^{-1}$ (Fig. 11). Both of the Nyquist plots are similar in shape except the diameter of approximate semi-circle in the high-frequency region. The diameter of $\mathrm{Zn}_{0.95} \mathrm{Co}_{2} \mathrm{O}_{4}$ 's is much smaller than the $\mathrm{ZnCo}_{2} \mathrm{O}_{4}$ 's, which suggests that the electron conductivity of the former is still better than the latter's after 200 cycles [48]. In addition, the $\mathrm{Zn}_{0.95} \mathrm{Co}_{2} \mathrm{O}_{4}$ electrode (the mixture of $\mathrm{Zn}_{0.95} \mathrm{Co}_{2} \mathrm{O}_{4} / \mathrm{ATB} / \mathrm{PVDF}$ ) under $0.4 \mathrm{~A} \cdot \mathrm{g}^{-1}$ after 200 cycles is also shown in Fig. 12. The SEM images clearly illustrate that the micro-structure of nanosheets is well maintained without collapse and shedding, so the excellent structural stability agrees 
well with the above advanced capacity retention.

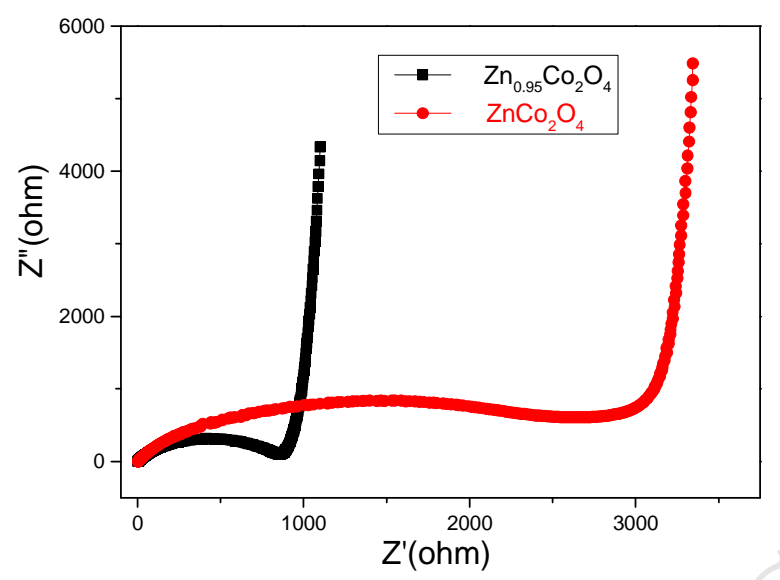

Fig. 11 Nyquist plots of $\mathrm{Zn}_{0.95} \mathrm{Co}_{2} \mathrm{O}_{4}$ and $\mathrm{ZnCo}_{2} \mathrm{O}_{4}$ electrodes under $0.4 \mathrm{Ag}^{-1}$ after 200 cycles measured with an amplitude of $10 \mathrm{mV}$ over the frequency range of $1 \mathrm{MHz}$ and $0.01 \mathrm{~Hz}$

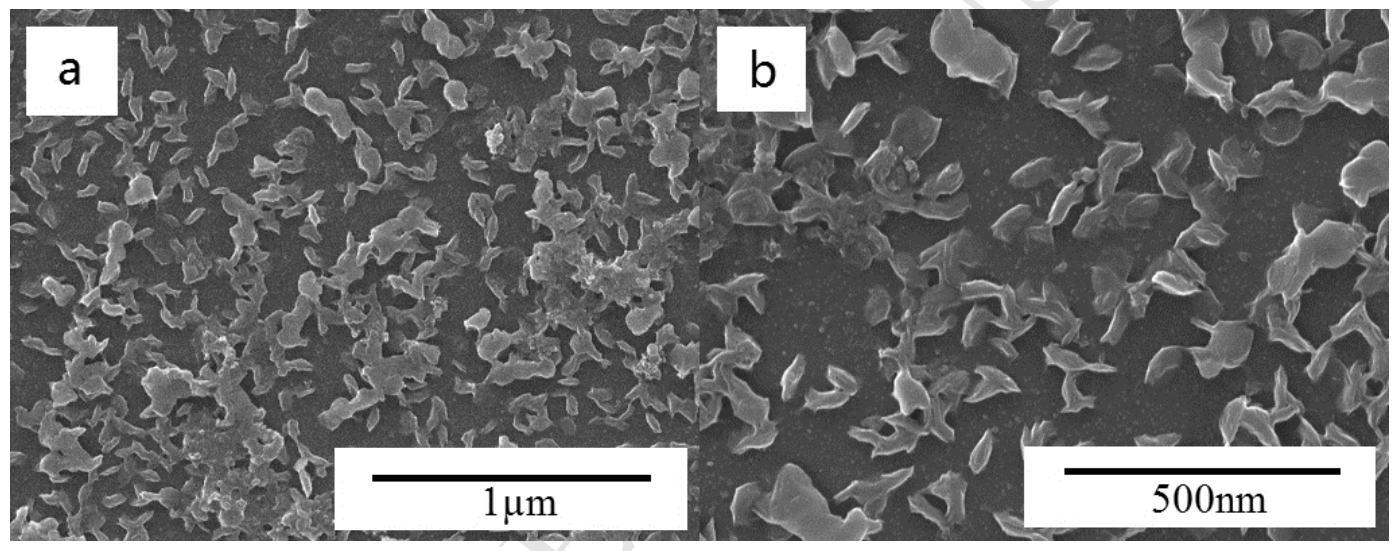

Fig. 12 SEM images of the $\mathrm{Zn}_{0.95} \mathrm{Co}_{2} \mathrm{O}_{4}$ electrode (the mixture of $\mathrm{Zn}_{0.95} \mathrm{Co}_{2} \mathrm{O}_{4} / \mathrm{ATB} / \mathrm{PVDF}$ ) under $0.4 \mathrm{Ag}^{-1}$ after 200 cycles

\section{Conclusions}

In summary, the defective $\mathrm{ZnCo}_{2} \mathrm{O}_{4}$ with $\mathrm{Zn}$ vacancies $\left(\mathrm{Zn}_{0.95} \mathrm{Co}_{2} \mathrm{O}_{4}\right)$ via the liquid-phase co-precipitation and alkaline-tailored method has been synthesized successfully. The $\mathrm{Zn}_{0.95} \mathrm{Co}_{2} \mathrm{O}_{4}$ powders are similar to the crystal phase, morphology, and particle size of the pure $\mathrm{ZnCo}_{2} \mathrm{O}_{4}$ before etched except the enlarged BET specific surface. The $\mathrm{Zn}$ vacancies in defective $\mathrm{ZnCo}_{2} \mathrm{O}_{4}$ may decrease the probability of the reversible by-reaction between $\mathrm{Zn}$ and $\mathrm{Li}-\mathrm{Zn}$ alloy through the $\mathrm{CV}$ measurement. Compared to the traditional $\mathrm{ZnCo}_{2} \mathrm{O}_{4}$, the $\mathrm{Zn}$ vacancies in the defective $\mathrm{ZnCo}_{2} \mathrm{O}_{4}$ can 
provide larger interface, activate more reaction sites and expand faster transport paths for both of Li-ions and electronics insertion/extraction, so the electrochemical performance of defective $\mathrm{ZnCo}_{2} \mathrm{O}_{4}$ has been enhanced highly. The discharge capacity retains at $652.2 \mathrm{mAh} \cdot \mathrm{g}^{-1}$ under $0.4 \mathrm{~A} \cdot \mathrm{g}^{-1}$ after 200 cycles. When the rate returns to 0.4 $\mathrm{Ah} \cdot \mathrm{g}^{-1}$, the average discharge capacity is recovered to $748.9 \mathrm{mAh} \cdot \mathrm{g}^{-1}$ under the multiple-step high rates after many cycles. Furthermore, this facile strategy may be extended to design and construct other electrode materials with atomic vacancies for conversion devices.

\section{AUTHOR INFORMATION}

\section{Corresponding Author}

*E-mail: smxu@tsinghua.edu.cn.

*E-mail: zhenghe.xu@ualberta.ca.

*E-mail: junlian@ualberta.ca.

\section{Notes}

The authors declare no competing financial interest.

\section{Acknowledgements}

This work was supported by the National Natural Science Foundation of China (Grant No. 51604306), the China Postdoctoral Science Foundation (Grant Nos. 2016M602426 and 2017T100609) and the Innovation-Driven Project of Central South University (Grant No. 2016CXS020).

\section{References}


(1) Y. Zhao, L.P. Wang, M.T. Sougrati, Z. Feng, Y. Leconte, A. Fisher, M. Srinivasan, Z. $\mathrm{Xu}$, A review on design strategies for carbon based metal oxides and sulfides nanocomposites for high performance $\mathrm{Li}$ and $\mathrm{Na}$ ion battery anodes, Adv. Energy Mater. 7 (2017) 1601424 (1-70).

(2) X.Y. Guo, X. Cao, G.Y. Huang, Q.H. Tian, H.Y. Sun, Recovery of lithium from the effluent obtained in the process of spent lithium-ion batteries recycling, J. Environ. Manag. 198 (2017) 84-89.

(3) B. Scrosati, J. Garche, Lithium batteries: status, prospects and future, J. Power Sources 195 (2010) 2419-2430.

(4) V. Etacheri, R. Marom, R. Elazari, G. Salitra, D. Aurbach, Challenges in the development of advanced Li-ion batteries: a review, Energy Environ. Sci. 4 (2011) 3243-3262.

(5) J. Mujtaba, H.Y. Sun, G.Y. Huang, Y.Y. Zhao, H. Arandiyan, G.Y. Sun, S.M. Xu, J. Zhu, $\mathrm{Co}_{9} \mathrm{~S}_{8}$ nanoparticles encapsulated in nitrogen-doped mesoporous carbon networks with improved lithium storage properties, RSC Adv. 2016 (6) 31775-31781.

(6) P. Poizot, S. Laruelle, S. Grugeon, L. Dupont, J.M. Tarascon, Nano-sized transition-metaloxides as negative-electrode materials for lithium-ion batteries, Nature 407 (2000) 496-499.

(7) G.Y. Huang, S.M. Xu, Y.B. Cheng, W.J. Zhang, J. Li, X.H. Kang, NiO nanosheets with large specific surface area for lithium-ion batteries and supercapacitors, Int. J. Electrochem. Sci. 10 (2015) 2594-2601.

(8) G.Y. Huang, S.M. Xu, Y. Yang, Y.B. Chen, Z.B Li, Rapid-rate capability of micro-/nano-structured $\mathrm{CoO}$ anodes with different morphologies for lithium-ion batteries, Int. J. Electrochem. Sci. 10 (2015) 10587-10596.

(9) G.Y. Huang, S.M. Xu, Y. Yang, Y.B. Cheng, J. Li, Preparation of cobalt-based bi-metal-oxides and the application in the field of electrochemical energy storage, Chinese J. Inorg. Chem. 32 (2016) 1693-1703.

(10) G.Y. Huang, S.M. Xu, Y. Yang, H.Y. Sun, Z.H. Xu, Synthesis of porous $\mathrm{MnCo}_{2} \mathrm{O}_{4}$ microspheres with yolk-shell structure induced by concentration gradient and the 
effect on their performance in electrochemical energy storage, RSC Adv. 6 (2016) 10763-10774.

(11) S. Abouali, M.A. Garakani, Z.L. Xu, J.K. Kim, $\mathrm{NiCo}_{2} \mathrm{O}_{4} / \mathrm{CNT}$ nanocomposites as bi-functional electrodes for Li ion batteries and supercapacitors, Carbon 102 (2016) 262-272.

(12) G.Y. Huang, W.J. Zhang, S.M. Xu, Y.J. Li, Y. Yang, Microspherical ZnO synthesized from a metal-organic precursor for supercapacitors, Ionics 22 (2016) 2169-2174.

(13) J.W. Jung, C.L. Lee, S. Yu, I.D. Kim, Electrospun nanofibers as a platform for advanced secondary batteries: a comprehensive review, J. Mater. Chem. A 4 (2016) 703-750.

(14) Q. Ru, X. Song, Y.D. Mo, L.Y. Guo, S.J. Hu, Carbon nanotubes modified for $\mathrm{ZnCo}_{2} \mathrm{O}_{4}$ with a novel porous polyhedral structure as anodes for lithium ion batteries with improved performances, J. Alloy. Compd. 654 (2016) 586-592.

(15) S.J. Hao, B.W. Zhang, S. Ball, M. Copley, Z.C. Xu, M. Srinivasan, K. Zhou, S. Mhaisalkar, Y.Z. Huang, Synthesis of multimodal porous $\mathrm{ZnCo}_{2} \mathrm{O}_{4}$ and its electrochemical properties as an anode material for lithium ion batteries, J. Power Sources 294 (2015) 112-119.

(16) A.K. Rai, T.V. Thi, B.J. Paul, J. Kim, Synthesis of nano-sized $\mathrm{ZnCo}_{2} \mathrm{O}_{4}$ anchored with graphene nanosheets as an anode material for secondary lithium ion batteries, Electrochim. Acta 146 (2014) 577-584.

(17) C.W. Lee, S.D. Seo, D.W. Kim, S. Park, K. Jin, D.W. Kim, K.S. Hong, Heteroepitaxial growth of $\mathrm{ZnO}$ nanosheet bands on $\mathrm{ZnCo}_{2} \mathrm{O}_{4}$ submicron rods toward high-performance Li ion battery electrodes, Nano Res. 6 (2013) 348-355.

(18) A.K. Giri, P. Pal, R. Ananthakumar, M. Jayachandran, S. Mahanty, A.B. Panda, 3D hierarchically assembled porous wrinkled-paper-like structure of $\mathrm{ZnCo}_{2} \mathrm{O}_{4}$ and Co-ZnO@C as anode materials for lithium-ion batteries, Cryst. Growth Des. 14 (2014) 3352-3359.

(19) S.H. Choi, Y.C. Kang, Yolk-shell, hollow, and single-crystalline $\mathrm{ZnCo}_{2} \mathrm{O}_{4}$ powders: preparation using a simple one-pot process and application in lithium-ion batteries, ChemSusChem 6 (2013) 2111-2116. 
(20) F. Tuomisto, V. Ranki, K. Saarinen, Evidence of the Zn vacancy acting as the dominant acceptor in $n$-type ZnO, Phys. Rev. Lett. 91 (2003) 205502 (1-4).

(21) S. Wendt, R. Schaub, J. Matthiesen, E.K. Vestergaard, E. Wahlstrom, M.D. Rasmussen, P. Thostrup, L.M. Molina, E. Lasgaard, I. Stensgaard, B. Hammer, F. Besenbacher, Oxygen vacancies on $\mathrm{TiO}_{2}(110)$ and their interaction with $\mathrm{H}_{2} \mathrm{O}$ and $\mathrm{O}_{2}$ : a combined high-resolution STM and DFT study, Surf. Sci. 598 (2005) 226-245.

(22) T.M. Borseth, B.G. Svensson, A.Y. Kuznetsov, Identification of oxygen and zinc vacancy optical signals in ZnO, Phys. Rev. Lett. 89 (2006) 262112 (1-3).

(23) X.Y. Pan, M.Q. Yang, X.Z. Fu, N. Zhang, Y.J. Xu, Defective $\mathrm{TiO}_{2}$ with oxygen vacancies: synthesis, properties and photocatalytic applications, Nanoscale, 5 (2013) 3601-3614.

(24) B. Bharti, S. Kumar, H.N. Lee, R. Kumar, Formation of oxygen vacancies and $\mathrm{Ti}^{3+}$ state in $\mathrm{TiO}_{2}$ thin film and enhanced optical properties by air plasma treatment, Sci. Rep. 6 (2016) 32355 (1-12).

(25) Y.C. Zhang, L. Pan, J.H. Lu, J.J. Song, Z. Li, X.W. Zhang, L. Wang, J.J. Zou, Unraveling the facet-dependent and oxygen vacancy role for ethylene hydrogenation on $\mathrm{Co}_{3} \mathrm{O}_{4}$ (110) surface: a DFT+U study, Appl. Surf. Sci. 401 (2017) 241-247.

(26) J.L. Wang, J.G. Li, C.J. Jiang, P. Zhou, P.Y. Zhang, J.G. Yu, The effect of manganese vacancy in birnessite-type $\mathrm{MnO}_{2}$ on room-temperature oxidation of formaldehyde in air, Appl. Catal. B-Environ. 204 (2017) 147-155.

(27) G.Y. Huang, S.M. Xu, L.Y. Li, X.J. Wang, Effect of surfactants on the dispersion property and morphology of nano-sized nickel powders, Trans. Nonferrous Met. Soc. China, 24 (2014) 3739-3746.

(28) Y. Yang, G.Y. Huang, S.M. Xu, Y.H. He, X. Liu, Thermal treatment process for the recovery of valuable metals from spent lithium-ion batteries, Hydrometallurgy 165 (2016) 390-396.

(29) Y. Yang, G.Y. Huang, M. Xie, S.M. Xu, Y.H. He, Synthesis and performance of spherical $\mathrm{LiNi}_{\mathrm{x}} \mathrm{Co}_{\mathrm{y}} \mathrm{Mn}_{1-\mathrm{x}-\mathrm{y}} \mathrm{O}_{2}$ regenerated from nickel and cobalt scraps, Hydrometallurgy 165 (2016) 358-369.

(30) G.Y. Huang, X.Y. Guo, X. Cao, Q.H. Tian, H.Y. Sun, Formation of graphene-like 2D 
spinel $\mathrm{MnCo}_{2} \mathrm{O}_{4}$ and its lithium storage properties, J. Alloy. Compd. 695 (2017) 2937-2944.

(31) G.Y. Huang, S.M. Xu, J.L. Wang, L.Y. Li, X.J. Wang, Recent development of $\mathrm{Co}_{3} \mathrm{O}_{4}$ and its composites as anode materials of lithium-ion batteries, Acta Chim. Sinica 71 (2013) 1589-1597.

(32) J. Mujtaba, H.Y. Sun, G.Y. Huang, K. Molhave, Y.G. Liu, Y.Y. Zhao, X. Wang, S.M. $\mathrm{Xu}, \mathrm{J}$. Zhu, Nanoparticle decorated ultrathin porous nanosheets as hierarchical $\mathrm{Co}_{3} \mathrm{O}_{4}$ nanostructures forlithium ion battery anode materials, Sci. Rep. 6 (2016) 20592 $(1-8)$.

(33) G. Brauer, W. Anwand, D. Grambole, J. Grenzer, W. Skorupa, Identification of Zn-vacancy-hydrogen complexes in $\mathrm{ZnO}$ single crystals: a challenge to positron annihilation spectroscopy, Phy. Rev. B 79 (2009) 115212 (1-15).

(34) L.C. Fernandez, F. Mueller, S. Passerini, L.J. Hardwick, In situ Raman spectroscopy of carbon-coated $\mathrm{ZnFe}_{2} \mathrm{O}_{4}$ anode material in Li-ion batteries-investigation of SEI growth, Chem. Commun. 52 (2016) 3970-3973.

(35) Z.Q. Liu, H. Cheng, N. Li, T.Y. Ma, Y.Z. Su, $\mathrm{ZnCo}_{2} \mathrm{O}_{4}$ quantum dots anchored on nitrogen-doped carbon nanotubes as reversible oxygen reduction/evolution electrocatalysts, Adv. Mater. 28 (2016) 3777-3784.

(36) K.W. Qiu, Y. Lu, D.Y. Zhang, J.B. Cheng, H.L. Yan, J.Y. Xu, X.M. Liu, J.K. Kim, Y.S. Luo, Mesoporous, hierarchicalcore/shell structured $\mathrm{ZnCo}_{2} \mathrm{O}_{4} / \mathrm{MnO}_{2}$ nanocone forests for high-performance supercapacitors, Nano Energy 11 (2015) 687-696.

(37) I.K. Moon, S. Yoon, J. Oh, Three-dimensional hierarchically mesoporous $\mathrm{ZnCo}_{2} \mathrm{O}_{4}$ nanowires grown on graphene/sponge foam for high-performance, flexible, all-solid-state supercapacitors, Chem. Eur. J. 23 (2017) 597-604.

(38) G. Rajeshkhanna, E. Umeshbabu, P. Justin, G.R. Rao, Spinel $\mathrm{ZnCo}_{2} \mathrm{O}_{4}$ nanosheets as carbon and binder free electrode material for energy storage and electroreduction of $\mathrm{H}_{2} \mathrm{O}_{2}$, J. Alloy. Compd. 696 (2017) 947-955.

(39) S.G. Mohamed, T.F. Hung, C.J. Chen, C.K. Chen, S.F. Hu, R.S. Liu, K.C. Wang, X.K. Xing, H.M. Liu, A.S. Liu, M.H. Hsiehe, B.J. Lee, Flower-like $\mathrm{ZnCo}_{2} \mathrm{O}_{4}$ nanowires: toward a highperformance anode material for Li-ion batteries, RSC Adv. 
3 (2013) 20143-20149.

(40) G. Huang, Q. Li, D.M. Yin, L.M. Wang, Hierarchical porous Te@ $\mathrm{ZnCo}_{2} \mathrm{O}_{4}$ nanofibers derived from Te@metal-organic frameworks for superior lithium storage capability, Adv. Funct. Mater. 27 (2017) 1604941 (1-7).

(41) G.Y. Huang, X.Y. Guo, X. Cao, Q.H. Tian, H.Y. Sun, 3D network single-phase $\mathrm{Ni}_{0.9} \mathrm{Zn}_{0.1} \mathrm{O}$ as anode materials for lithium-ion batteries, Nano Energy 28 (2016) $338-345$.

(42) J. Bai, X.G. Li, G.Z. Liu, Y.T Qian, S.L. Xiong, Unusual formation of $\mathrm{ZnCo}_{2} \mathrm{O}_{4} 3 \mathrm{D}$ hierarchical twin microspheres as a high-rate and ultralong-life lithium-ion battery anode material, Adv. Funct. Mater. 24 (2014) 3012-3020.

(43) R.Z. Chen, Y. Hu, Z. Shen, Y.L. Chen, X. He, X.W. Zhang, Y. Zhang, Controlled synthesis of carbon nanofibers anchored with $\mathrm{Zn}_{\mathrm{x}} \mathrm{Co}_{3-\mathrm{x}} \mathrm{O}_{4}$ nanocubes as binder-free anode materials for lithium-ion batteries, ACS Appl. Mater. Interfaces 8 (2016) 2591-2599.

(44) Y. Yang, S.M. Xu, M. Xie, Y.H. He, G.Y. Huang, Y.C. Yang, Growth mechanisms for spherical mixed hydroxide pellets prepared by co-precipitation method: a case of $\mathrm{Ni}_{1 / 3} \mathrm{Co}_{1 / 3} \mathrm{Mn}_{1 / 3}(\mathrm{OH})_{2}$, J. Alloy. Compd. 619 (2015) 846-853.

(45) J.L. Huang, F. Fang, G.Y. Huang, H.Y. Sun, J. Zhu, R. Yu, Engineering the surface of rutile $\mathrm{TiO}_{2}$ nanoparticles with quantum pits towards excellent lithium storage, RSC Adv. 6 (2016) 66197-66203.

(46) H.J. Park, J. Kim, N.J. Choi, H. Song, D.S. Lee, Nonstoichiometric Co-rich $\mathrm{ZnCo}_{2} \mathrm{O}_{4}$ hollow nanospheres for high performance formaldehyde detection at ppb levels, ACS Appl. Mater. Interfaces 8 (2016) 3233-3240.

(47) Y. Sharma, N. Sharma, G.V.S. Rao, B.V.R. Chowdari, Nanophase $\mathrm{ZnCo}_{2} \mathrm{O}_{4}$ as a high performance anode material for Li-ion batteries, Adv. Funct. Mater. 17 (2007) 2855-2861.

(48) P.F. Teh, Y. Sharma, Y.W. Ko, S.S. Pramanaad, M. Srinivasan, Tuning the morphology of $\mathrm{ZnMn}_{2} \mathrm{O}_{4}$ lithium ion battery anodes by electrospinning and its effect on electrochemical performance, RSC Adv. 3 (2013) 2812-2821. 


\section{Highlights}

1. The defective $\mathrm{ZnCo}_{2} \mathrm{O}_{4}$ with $\mathrm{Zn}$ vacancies has been synthesized via the alkaline-tailored method.

2. The $\mathrm{Zn}$ vacancies may decrease the probability of the reversible by-reaction between $\mathrm{Zn}$ and $\mathrm{Li}-\mathrm{Zn}$ alloy.

3. The discharge capacity retains at $652.2 \mathrm{mAh} \cdot \mathrm{g}^{-1}$ under $0.4 \mathrm{~A} \cdot \mathrm{g}^{-1}$ after 200 cycles.

4. When the rate returns to $0.4 \mathrm{Ah} \cdot \mathrm{g}^{-1}$, the average discharge capacity is recovered to $748.9 \mathrm{mAh} \cdot \mathrm{g}^{-1}$ under multiple-step high rates. 